This is an Accepted Manuscript of an article published by Taylor \& Francis in Journal of Teaching in Travel \& Tourism on 16 May 2013, available online:

http://www.tandfonline.com/doi/full/10.1080/15313220.2013.786309

JTTT TEFI special issue on leadership for transformation - EDITORS' NOTE

\title{
Leadership for Transformation in Tourism Education
}

\author{
Dr Christian Schott \\ School of Management \\ Victoria University of Wellington \\ Wellington, New Zealand \\ Dr Ulrike Gretzel \\ Institute for Innovation in Business and Social Research \\ University of Wollongong \\ Wollongong, Australia
}

In light of ever greater financial and philosophical attacks on tourism higher education across the world, it is critical to contemplate the role of tourism education at university level and its place in modern societies. This need for reflection is given urgency by increasingly neoliberal education policies, market-driven universities, and 'consumers' with distinctive demands that are able to choose from a growing variety of educational 'products'. Often relegated to an area of specialization within business studies, tourism is increasingly under pressure to demonstrate its value, which is commonly interpreted as producing graduates with industry-ready skills and good immediate job prospects. This focus has led to tourism higher education that seeks to cater to industry needs and is fundamentally vocational. In doing so it is at the mercy of an industry that still largely subscribes to the dream of the self-made leader/entrepreneur, who emerges in a senior managerial position at the end of a career path that starts with washing dishes and/or cleaning toilets, rather than actively promoting and rewarding formal education. This lack of appreciation and support from the industry it seeks to serve presents significant challenges for 
tourism higher education. Additionally, tourism is also exposed to challenges from within the academy where the above outlined image can lead to tourism programs being looked down upon by other programs and where it is ultimately vulnerable to restructuring and cost cutting measures. However, despite of these profound challenges we believe that tourism higher education delivers a unique and valuable contribution to higher education and that there is thus an urgent need for tourism academics to critically reflect on the status quo, and subsequently act as advocates and agents for transformation of tourism education and research in the academy.

Historically, tourism has undersold itself and it has thus far failed to fully explore its capacity to substantially contribute to society and to higher education. Being an 'indiscipline' (Tribe, 1997), tourism provides unique opportunities for inquiry that have the potential to lead to significant changes in the world. From this perspective, its foremost goal should not be the production of mindless laborers but of leaders who have the potential and the desire to transform in all areas and at all levels. Transformational leadership as a concept has been written about quite extensively in the management literature (e.g. Bass \& Riggio, 2006). Transformational leaders are those who initiate change and inspire others to take on leadership responsibilities. Transformational leadership is essentially about impact (Bass, 1985).

Bass and Riggio (2006) describe the components to transformational leadership as:

1. Idealized Influence - the leader serves as an ideal role model for followers and is admired for 'walking the talk'.

2. Inspirational Motivation - Transformational leaders have the ability to inspire and motivate followers. 
3. Individualized Consideration - By paying personal attention to each follower, transformational leaders demonstrate genuine concern and bring out the very best efforts in individuals.

4. Intellectual Stimulation - the leader challenges followers to be innovative and creative.

Leadership for transformation then expands on this concept by envisioning leaders that not only strive to instill a passion and avenues for transformation in their 'followers' but actively seek to transform the broader environment around them at the same time, both individually and collectively. The main argument on which this special issue is based is, thus, that tourism higher education has tremendous potential to cultivate leaders who can fundamentally transform the tourism industry and create positive impacts on individuals, destinations, the natural environment and global society. These leaders need to be equipped not only with leadership skills and intricate knowledge of tourism as a complex phenomenon, but also require a value system which informs their decision-making in an ever changing world. Value-based education has been a central focus of discussion at the Tourism Education Futures Initiative's (TEFI) forums. At the sixth TEFI conference in Milan in 2012, which was hosted by Bocconi University, value-based education was specifically linked to leadership for transformation to explore opportunities in which tourism education could be used to actively create a more sustainable and equitable future. It therefore followed directly from TEFI V's goal of 'Activating Change in Tourism Education' (Gretzel et al., 2012), which was the theme of the 2011 TEFI World Congress held at Temple University in Philadelphia. Erica Wilson and Jennie Small's conference report included in this special issue presents in detail the structure and specific activities that formed the basis of TEFI VI in Milan. The report also reflects on the conference outcomes, which included working groups on (a) the facilitation of innovative, value-based learning experiences, (b) reshaping 
tourism scholarship, (c) the impact of future socio-economic trends and (d) advocacy for tourism as a field of study and employment. These working groups exemplify the passion and drive of both the tourism academy as a collective and of individuals to provide leadership direction and inspiration.

This issue is the third special issue in JTTT dedicated to TEFI and its goals; the first was published in 2011 (Volume 11(1)) and the second in 2012 (Volume 12(2)) following the fifth meeting in Philadelphia. The papers in this special issue on leadership for transformation explore the role and potential of education and educators to transform both tourism and tourism education. Additionally, academic agency and other means of restructuring tourism education to focus more on developing leadership potential in its graduates and equip them with the skills as well as the values necessary to engage in leadership for transformation are discussed. The authors represent a variety of institutions and the case studies presented span across the globe. They provide insights into TEFI as a forum that embraces critical thinking and challenges the status quo.

The paper by Dianne Dredge and Christian Schott discusses the agency tourism academics have in initiating change in the higher education system. They conclude that tourism academics not only have an important role but also a responsibility to students, the tourism industry and society to unlock the potential of tourism to improve the human condition. However, they identify a range of obstacles to academic agency, some of which are systemic, and offer some suggestions on how leadership could be exhibited by tourism academics. Similarly, Erica Wilson and Tania von der Heidt look at the transformational potential of tourism academics within the context of a 
first year business/tourism curriculum. Like Dredge and Schott, they identify the role of the academic teacher as a transformational agent as particularly important but, unfortunately, reveal a number of barriers that make faculty-initiated transformational change in tourism quite difficult. Carlos Costa, Sandra Caçador, Inês Carvalho and Zélia Breda discuss the structural issues that keep women from becoming transformational leaders, while Gretzel and Bowser argue that tourism students in general, and especially female students, need role models that inspire them to take on leadership roles and that storytelling can play a significant part in communicating role models. Finally, Montserrat Iglesias Xamaní, David Peguero Mananares, and Gloria Sanmartín Antolín illustrate how important leadership for transformation is for tourism higher education in developing countries, where the focus on industry needs appears to be especially pronounced. Overall, the papers jointly demonstrate that it is critical to create facilitating conditions for academics to role model transformational leadership and leadership for transformation to students and to implement relevant changes in curricula. They therefore constitute a clear call to the administrators of higher education institutions with tourism programs to give academics the necessary agency and support transformational initiatives.

The seventh TEFI meeting is held in April 2013 in Oxford and hosted by Oxford Brookes University. The theme of the conference is 'Tourism Education for Global Citizenship: Educating for lives of consequence'. For more information about TEFI, its goals, publications, initiatives and meetings in different parts of the world please see http://www.tourismeducationfutures.org/ 


\section{Acknowledgements}

The guest editors would like to thank Professor Cathy Hsu for providing this opportunity for a special issue in the Journal of Teaching in Travel and Tourism and all reviewers for their hard work and critical and constructive comments. Additionally, the TEFI committee would like to thank Professor Magda Antonioli and her excellent team at Bocconi University for hosting the inspiring conference from which these papers have developed.

\section{References}

Bass, B. M. (1985). Leadership and Performance. New York: Free Press.

Bass, B. M. \& Riggio, R. E. (2006). Transformational Leadership (2nd Ed.). Mahwah, NJ: Lawrence Erlbaum Associates.

Gretzel, U., Prebežac, D., Joppe, M., \& Edwards, D. (2012). TEFI 2011 World Congress “Activating Change in Tourism Education” May 18-21, 2011, Philadelphia, Pennsylvania, United States. Conference Report. Journal of Teaching in Travel and Tourism, 12(1), 118-122.

Tribe, J. (1997). The indiscipline of tourism. Annals of Tourism Research, 24(3), 638-657. 